\title{
Use of Information Communication Technology (ICT) in Teaching Profession in Ogun State, Nigeria
}

\author{
Wasiu Oyeleke Oyediran \\ Federal University of Agriculture, \\ Abeokuta, Nigeria
}

\author{
Tenneh Theresa Dick \\ Rokupr Agriculture Rice Centre, Sierra \\ Leone
}

\begin{abstract}
This study was born out of the underuse of ICT in teachers' education coupled with the resulting lack of technical knowledge pertaining to integrating these tools in the teaching-learning process. Hence, this study was carried out to assess the use of Information Communication Technology (ICT) in teaching profession in Ogun State, Nigeria. Simple random sampling technique was used to select 90 Student-teachers in Federal College of Education, Abeokuta as sample size for this study. Data obtained were analyzed using descriptive statistics and Pearson Product Moment Correlation (PPMC). Result of the findings showed that the mean age of the respondents was 30.2 years. Most (60.0\%) of the respondents were females and married. The average teaching experience was 4.2 years. Above $70 \%$ of the respondents did not possess Laptop, Desktop, Tablet, Modem and I-pads hence, they did not use ICT for lesson note write up and teaching in the class. Myriads of problems such as high cost of ICT facilities and equipment, inadequate training and seminar on ICT, epileptic power supply and poor network service by network providers affected the efficient use of ICT by the Student-teachers. Significant relationship existed between personal characteristic of the respondents and use of ICT in teaching profession at $p<0.05$. The study concludes that younger teachers have great potential to the use of ICT in teaching profession. It is hereby recommends that the use of ICT for teaching and learning in Nigeria schools should be encouraged while teachers must receive in-service training to be able to comply with ICT usage and perform effectively in their teaching profession which will ultimately be of benefit to the students.
\end{abstract}

Keywords: Usage, ICT, Teaching, Ogun

\section{Introduction}

Why should schools and teachers work towards increasing the use of ICT in education? There are two main reasons. Firstly, consider the potential of ICT to change the nature of work and leisure over the next two decades. Today's children need to develop the skills which will enable them to benefit from new opportunities offered by ICT. Secondly, there is a growing body of academic research, such as the Interactive Education project at Bristol University in the UK, which demonstrates how ICT enhances the quality of teaching and learning in schools, and thus contributes to the raising of standards of achievement in education (www.interactiveeducation.ac.uk). In Nigeria, teacher education is gaining prominence because of the need for qualified teachers with the necessary skills and knowledge needed to adequately carry out teaching jobs as well as for professional growth [14]. Teacher education is the process of training that deals with the art of acquiring professional competencies and growth. It is an essential exercise that enhances the skills of teaching and learning. It is designed to produce highly motivated, sensitive, conscientious and successful classroom teachers who handle students effectively and professionally for better educational achievement [11]. Effective teaching could be facilitated through advances in computer and telecommunication technology, in addition to the ever-evolving worldwide web, which has become a major force to reckon with in searching for and dissemination of information. Information and Communication Technologies (ICTs) are key tools and have revolutionary impact on how we see the world and live in it. This phenomenon gave origin to contemporary advances in living standard. It is having a revolutionary impact on educational methodology globally. However, this revolution is not widespread and needs to be strengthened to be able to make a significant change in the traditional system of teaching and learning in Nigeria. In a complex society like Nigeria, many factors affect the use of ICT and integration including a lack of funds to buy equipment, a lack of funds to hire personnel trained to use ICT and the nonchalant attitude of teachers when it comes to embracing modern computer-driven methods of teaching. Therefore, an interdisciplinary and integrated approach is very necessary to ensure the successful development of teacher education programmes [9]. Many Nigerian teachers have been unable to find effective ways to use technology in the classroom or in any other aspect of their teaching and learning life. One possible explanation for this problem is that the use of technology in the classroom has not been widely encouraged and the teachers are not well trained in 
how to use ICTs as educational tools [13], notwithstanding specifications in the National Policy of Education by the Federal Government of Nigeria [22]. Nigeria as a nation came late and slowly into the use of ICT in all sectors, especially teacher education. Compounding all of this is the fact that most teachers in Nigeria do not have the experience and competence needed to use ICT facilities. This is a result of chronic limitations imposed by both economic disadvantages and poor government policies on education. Consequently, it affects the nation's educational development. A recent study by Global Information Technology [20] used the Networked Readiness Index (NRI), which covered 115 economies in 2005-2006, to measure the degree of preparation of a nation or community to participate in and benefit from ICT developments. Nigeria ranked 90th of the 115 countries surveyed, while the United States of America topped the list followed by Singapore, Denmark, Iceland, Finland, Canada, Taiwan, Sweden, Switzerland and the United Kingdom. In 2004, Nigeria ranked 86th of the 104 countries surveyed [24], suggesting a decline in Nigeria's preparedness to participate in and benefit from ICT development globally. It is against this background that this study becomes imperative to assess the use of information communication technology (ICT) in teaching profession in Ogun State, Nigeria.

The specific objectives of this study are to:

i. describe the personal characteristics of the studentteachers in the study area.

ii. assess the level of possession of ICTs facilities among the respondents in the study area.

iii. determine the effectiveness of the use of ICT in teacher education in the study area.

iv. identify the constraints to the use of ICT in education in the study area.

Hypothesis:

$\mathrm{H}_{01}$ : There is no significant relationship between personal characteristics of the respondents and use of ICT in teaching profession.

\section{Review of Literature}

\subsection{Uses of ICT in Teaching Profession}

The pervasiveness of ICT has brought about rapid changes in technology and social, political and economic transformation globally and the field of education has not been unaffected by its penetrating influence. Undoubtedly, ICTs has qualitatively and quantitatively impacted on teaching, learning and research through teacher education. Therefore, ICT provides opportunities for student-teachers, academic and non-academic staff to communicate with one another effectively during formal and informal teaching and learning [19].
In the same vein, teachers need training not only in computer literacy but also in the application of various kinds of educational software to teaching and learning [13]. ICT facilitates the acquisition and absorption of knowledge. It offers developing countries unprecedented opportunities to enhance educational systems, improve policy formulation and execution and widen the range of opportunities for the poor [2]. Thus, ICT stands as a diverse set of technological tools and materials used to communicate, create, store, manage and disseminate information. These technologies include computers, internet broadcasting, television and telephone [2]. Information and Communication Technologies are very useful. It helps to develop skills as it provides effective training programmes. It has capacity for stimulation, model-building and interactive adaptation. Its usage applies not only to the sciences and languages but also to other various professional courses. ICTs could assist in the development of administrative skills related to students' management, tutoring, course writing and pedagogic skills in education.

Haddad and Draxier [3] claim that ICTs do make valuable contributions to educational development and effective learning by expanding access, promoting efficiency, improving the quality of learning, enhancing the quality of teaching and improving management systems. Roberts [17] looks at how the use of technology can enhance teaching and learning by improving students' achievement and providing access to a variety of education materials. According to Obunadike [25], ICT aids learning by breaking down the barriers between teachers and students, improves the socio-cultural behavioural patterns of students, improves ethical awareness of students to the norms and existing moralities of the immediate community, serves as an agent of change, and helps disseminate ideas, educational materials and instructional resources.

Olakulehin [10] says that pedagogic application of ICT involves effective learning with the aid of computers and other information technologies. It serves the purpose of learning aids which play complementary roles in teaching/learning situations, rather than supplements to the teacher/instructor/facilitator. Many teachers regard computers as add-on, rather than a replacement device. The pedagogic use of the computer necessitates the development of skills and attitudes related to effective use of information and communication technologies among teachers and students. Aside from literacy, ICT facilitates learning in subject areas and at home on one's own. It further leads to the use of new methods like modeling, simulation, use of data bases, guided discovery, and closed-word exploration. The implications in terms of changes in teaching strategy, instructional content, role of the teachers and context of the curricula are 
obvious and inevitable. Pedagogy through the application of information and communication technologies has the advantage of heightening motivation, helping to recall previous learning, providing new instructional stimuli, activating the learner's response, providing systematic and steady feedback, facilitating appropriate practice, sequential learning appropriately and providing a viable source of information for enhanced learning. Teachers who use this system of instructional strategy would be able to kindle desirable attitudes towards information technology in the heart of the learners.

In additional, the use of ICT often creates situations where students must work together. The discussions and debates which arise bring a new dimension to the learning experience, where spontaneous lively communication leads to initial ideas being challenged, and thus the need to re-assess conclusions, make compromises and reach agreements.

ICT facilitates sharing of resources, expertise and advice; greater flexibility when and where tasks are carried out; gains in ICT literacy skills, confidence and enthusiasm; easier planning and preparation of lessons and designing material and access to up-todate pupil and school data, anytime and anywhere [29]. Also, students are generally more 'on task' and express more positive feelings when they use computers than when they are given other tasks to do [30]. Computer use during lessons motivated students to continue using learning outside school hours [30], [31].

\section{Contributions of ICTs to students learning process}

Contributions of ICT to learning include higher quality lessons through greater collaboration between teachers in planning and preparing resources [32], more focused teaching, tailored to students' strengths and weaknesses, through better analysis of attainment data, improved pastoral care and behaviour management through better tracking of students, gains in understanding and analytical skills, including improvements in reading comprehension [33] and development of writing skills (including spelling, grammar, punctuation, editing and redrafting), also fluency, originality and elaboration. Encouragement of independent and active learning, and self-responsibility for learning, flexibility of 'anytime, anywhere' access is achieved [37]. It helps in the development of higher level learning styles, students who used educational technology in school felt more successful in school, were more motivated to learn and have increased self-confidence and selfesteem [34]. Similarly, students found learning in a technology-enhanced setting more stimulating and student-centered than in a traditional classroom. Broadband technology supports the reliable and uninterrupted downloading of web-hosted educational multimedia resources, opportunities to address their work to an external audience and collaborate on assignments with people outside or inside school [26], [27], [28].

ICT in teaching and learning are most commonly used for three important educational activities, that is, Research, Training and Extension:

\subsection{Research}

Students can use ICT to find out information and to gain new knowledge in several ways. They may find information on the Internet or by using an ICTbased encyclopedia such as Microsoft Encarta. They may find information by extracting it from a document prepared by the teacher and made available to them via ICT, such as document created using Microsoft Word or a Microsoft PowerPoint slideshow. They may find out information by communicating with people elsewhere using email, such as students in a different school or even in a different country.

\subsection{Training (Processing knowledge)}

Students can use ICT as part of a creative process where they have to consider more carefully the information which they have about a given subject. They may need to carry out calculations (e.g. by using Microsoft Excel), or to check grammar and spelling in a piece of writing (perhaps using Microsoft Word), or they may need to re-sequence a series of events (for example by re-ordering a series of Microsoft PowerPoint slides).

\subsection{Extension (Sharing knowledge)}

Students can use ICT to present their work in a highly professional format. They can create documents and slideshows to demonstrate what they have learned, and then share this with other students, with their teacher, and even via email with people all around the world. Agricultural extension service uses such a platform for disseminating innovation to the farmers since it is their main mandate to help farmers increase productivity and enhance a better living.

\section{Methodology}

\subsection{Sampling Procedure and sample size}

The population for this study comprised of all student-teachers at the on-going Professional Diploma in Education (PDE) programme in Federal College of Education, Osiele, Abeokuta, Ogun State; most of them are teachers in Primary and Secondary Schools while very few are would-be teachers or 
proprietors. Ninety (90) respondents were randomly selected from the list of 167 registered studentteachers as sample size for this study.

\subsection{Data collection}

Data for this study were collected through the use of questionnaire. The instrument was subjected to face and content validity involving experts in Teaching Education and ICT. Items found ambiguous were removed. Test re-test method was carried out at interval of two weeks with studentteachers that are not included in the sample size for this study.

\subsection{Measurement of Variables}

Age and teaching experience were measured at interval level while sex, educational qualification and marital status were measured at nominal level. Respondents were asked to indicate the various ICT facilities in their possession. Problems to effective use of ICT were ranked based on their severity.

\subsection{Data Analysis}

Descriptive statistics such as frequency distribution, percentages and mean were used for objectives while Pearson Product Moment Correlation (PPMC) was used for the hypothesis of this study.

\section{Results and Discussion}

\subsection{Personal characteristics of the respondents}

Result in Table 1 showed that the mean age of the respondents was 30.22 years. Most $(96.7 \%)$ of the respondents were less than 35 years of age. It shows that the respondents are economically active. The finding is in tandem with that of Oyediran and Omoare [15] that people within this age bracket are full of energy and economically active. Majority $(60.0 \%)$ of the respondents were females while $(40.0 \%)$ were males. This shows the dominance of the female student-teachers in the PDE programme. Oyediran et al. [16] reported that predominant of female students may not be unconnected with the mandate of colleges of education to produce young qualified teachers which stimulates ladies to seek admission into teaching profession. If well harness, the implication is that high population of the female in teaching profession will assist in boosting knowledge and skill transfer to the students. There is a common saying that "teach a woman, teach a nation". Most $(70.0 \%)$ of the respondents were married while $30.0 \%$ were not married. This implies that they are responsible since marriage confers some level of responsibilities on the married people and it will go a long way in better teaching and caring for the students. All (100\%) the respondents were graduates and had acceptable qualifications from various Nigerian Institutions. This shows that the respondents are literates and this will facilitate rapid adoption of new innovations and use of ICT in teaching profession. The mean year of teaching experience was 4.17 years. It means that the respondents have not stayed long in teaching profession in the study area. Meanwhile, $4.40 \%$ of the respondents have spent more than 9 years while 95.6\% have spent less than 9 years. It means they still have more years in service and it will be an advantage if the government can train them on use of ICT to enhance their efficiency and service delivery.

Table 1. Distribution based on the personal characteristics of the respondents $(n=90)$

\begin{tabular}{|l|l|l|l|}
\hline Variables & Frequency & Percentage & Mean \\
\hline Age & & & \\
\hline$\geq 24$ & 07 & 7.80 & 30.20 \\
\hline $25-29$ & 21 & 23.30 & \\
\hline $30-34$ & 59 & 65.60 & \\
\hline Above 35 & 03 & 3.30 & \\
\hline Sex & & & \\
\hline Male & 36 & 40.00 & \\
\hline Female & 54 & 60.00 & \\
\hline Marital status & & & \\
\hline Married & 63 & 70.00 & \\
\hline Not married & 27 & 30.00 & \\
\hline $\begin{array}{l}\text { Education } \\
\text { qualification }\end{array}$ & & & \\
\hline MSc & 05 & 5.60 & \\
\hline BSc & 30 & 33.30 & \\
\hline HND & 55 & 61.10 & \\
\hline $\begin{array}{l}\text { Teaching } \\
\text { Experience } \\
\text { (yrs.) }\end{array}$ & & & \\
\hline$\leq 3$ & 48 & 53.30 & 4.17 \\
\hline $4-6$ & 23 & 25.60 & \\
\hline $7-9$ & 15 & 16.70 & \\
\hline Above 9 & 04 & 4.40 & \\
\hline Source: Fis Survey, & & \\
\hline
\end{tabular}

Source: Field Survey, 2016

\subsection{Possession of ICT facilities}

The result showed that above $70 \%$ of the respondents did not possess Laptop, Desktop, Tablet, Modem, and I-pads. However, almost all (96.7\%) the respondents have personal mobile phone (Android) and $43.30 \%$ accessed public internet. 


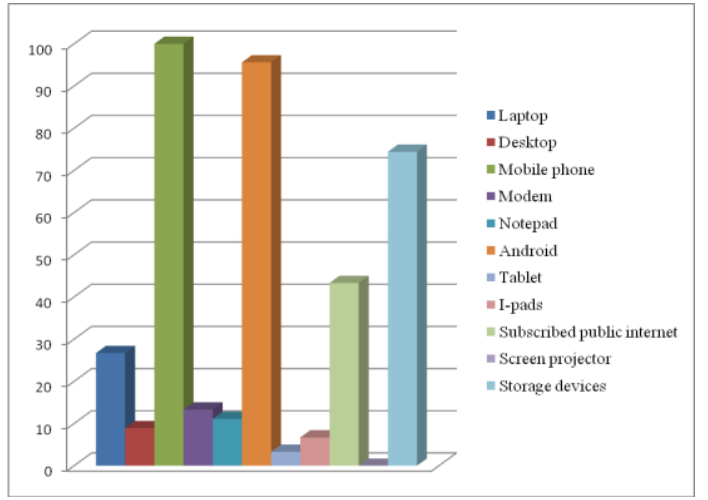

Figure 1: Respondents' possession of ICT facilities Source: Field Survey, 2016

\subsection{Uses of ICT}

The result on ICT utilization revealed that majority $(86.70 \%)$ of the respondents used ICT facilities to browse social network and chatting while few $(26.7 \%)$ use it for browsing academic materials. The finding agrees with that of Boyd and Ellisor [35] who reported that teenagers and adults have especially embraced Social Network Tools (SNTs) as a way to connect with peers and share information However, none of the respondents used ICT for lesson note, teaching and personal business. Also, result in Table $3 \mathrm{~b}$ indicated low level of ICT use for teaching among the student-teachers.

Table 2a. Distribution according to the use of ICT by respondents $(\mathrm{n}=90)$

\begin{tabular}{|c|c|c|c|}
\hline Utilization & $\begin{array}{l}\text { Very } \\
\text { often }\end{array}$ & Often & Not at all \\
\hline $\begin{array}{ll}\text { Use } & \text { for } \\
\text { teaching } & \end{array}$ & $0(0.00)$ & $0(0.00)$ & $90(100.00)$ \\
\hline $\begin{array}{ll}\text { Use for } \\
\text { browsing } \\
\text { academic } \\
\text { materials }\end{array}$ & $24(26.70)$ & $30(33.30)$ & $36(40.00)$ \\
\hline $\begin{array}{l}\text { Use for } \\
\text { preparing } \\
\text { lesson note }\end{array}$ & $0(0.00)$ & $0(0.00)$ & $90(100.00)$ \\
\hline $\begin{array}{l}\text { Use for social } \\
\text { networking } \\
\text { and chatting }\end{array}$ & $78(86.70)$ & $7(7.80)$ & $5(5.50)$ \\
\hline $\begin{array}{l}\text { Use for news } \\
\text { and sports }\end{array}$ & $3(3.30)$ & $10(11.10)$ & $77(85.60)$ \\
\hline $\begin{array}{ll}\text { Use for } & \text { for } \\
\text { personal } & \\
\text { business } & \end{array}$ & $0(0.00)$ & $0(0.00)$ & $90(100.00)$ \\
\hline
\end{tabular}

Source: Field Survey, 2016

Note: All figures in parenthesis are percentages
Table 2b. Categorization of level of ICT use by respondents $(n=90)$

\begin{tabular}{|l|l|l|l|}
\hline Level & Scores & Frequency & Percentage \\
\hline $\begin{array}{l}\text { High } \\
\text { use }\end{array}$ & $10-18$ & 29 & 32.20 \\
\hline $\begin{array}{l}\text { Low } \\
\text { use }\end{array}$ & $1-9$ & 61 & 67.80 \\
\hline
\end{tabular}

Source: Field Survey, 2016

\subsection{Problems confronting the use of ICT}

Across Africa and most developing countries, there are a number of barriers to integrating ICTs into teacher training and in the educative process in general, Nigeria is not an exception. These problems include ICT is too expensive for teachers to purchase (90\%), inadequate training/seminar on ICT $(83.3 \%)$, epileptic power supply $(82.2 \%)$, poor connectivity and network service $(80.0 \%)$, high cost of maintenance and technical support (74.4\%), and technophobia $(55.6 \%)$. These findings affirmed the submission of Ololube, [12] that ICT infrastructure (facilities and competent staff); a lack of information and information illiteracy among teachers and teacher trainers; technophobia; poor or nonexistent Internet connectivity; inadequate learning resources including related educational tools, course curriculum and other learning materials; attitudes of teacher trainees and teacher trainers in terms of a lack of independent learning skills and/or a reluctance to take responsibility for their own learning; highly prohibitive costs associated with software licenses, maintenance and technical support; and poor or irregular power supply, a problem that is peculiar to Nigeria in particular. The result also corroborates the findings of Hedjazi et al. [36] that poor state of infrastructure and manpower development affect efficient use of ICT.

Table 3. Problems confronting the respondents in using ICT facilities $(\mathrm{n}=90)$

\begin{tabular}{|l|l|l|l|}
\hline Problems & Serious & $\begin{array}{l}\text { Not } \\
\text { serious }\end{array}$ & Rank \\
\hline $\begin{array}{l}\text { ICT is too expensive } \\
\text { for teachers to } \\
\text { purchase }\end{array}$ & 90.0 & 10.0 & $1^{\text {st }}$ \\
\hline $\begin{array}{l}\text { Inadequate } \\
\text { training/seminar on } \\
\text { ICT }\end{array}$ & 83.3 & 16.7 & $2^{\text {nd }}$ \\
\hline $\begin{array}{l}\text { Epileptic power } \\
\text { supply }\end{array}$ & 82.2 & 17.8 & $3^{\text {rd }}$ \\
\hline $\begin{array}{l}\text { Poor connectivity and } \\
\text { network service }\end{array}$ & 80.0 & 20.0 & $4^{\text {th }}$ \\
\hline $\begin{array}{l}\text { High cost of } \\
\text { maintenance and } \\
\text { technical support }\end{array}$ & 74.4 & 25.6 & $5^{\text {th }}$ \\
\hline
\end{tabular}




\begin{tabular}{|l|l|l|l|}
\hline Technophobia & 55.6 & 44.4 & $6^{\text {th }}$ \\
\hline
\end{tabular}

\subsection{Hypothesis testing}

The result in table 4 showed a positive and significant relationship between age $(\mathrm{r}=0.73, \mathrm{p}=$ $0.00)$, teaching experience $(\mathrm{r}=0.81, \mathrm{p}=0.03)$ and use of ICT at $\mathrm{p}<0.05$. This implies that the younger and less experienced teachers are more likely to adopt the use of ICT in teaching while the older and highly experienced teachers may object the use of ICT in preparing lesson note and class teaching. Thus, the null hypothesis that "there is no significant relationship between personal characteristic of the respondents and use of ICT in teaching profession" is rejected while the alternate hypothesis is accepted.

Table 4. Relationship between personal characteristic and use of ICT

\begin{tabular}{|l|l|l|l|}
\hline Variables & r & p-value & Decision \\
\hline Age & 0.73 & 0.00 & $\mathrm{~S}$ \\
\hline $\begin{array}{l}\text { Teaching } \\
\text { experience }\end{array}$ & 0.81 & 0.03 & $\mathrm{~S}$ \\
\hline
\end{tabular}

Source: Field survey, 2016

$\mathrm{S}-$ Significant at $\mathrm{p}<0.05$ level of significance

\section{Conclusion}

ICT and teaching today are interdependent, for one to be an efficient teacher in modern society he or she thus must be ICT-compliance. It can be concluded that younger teachers have great potential to the use of ICT in teaching profession. Meanwhile, there are many problems affecting the use of ICT among the young student-teachers in the study area.

\section{Recommendations}

Based on the findings of this study, the following recommendations are made:

1. The use of ICT for teaching and learning in our schools should be encouraged public enlightenment.

2. Student-teachers must receive in-service training that renders them relevant to today's knowledge age and thus equips them with ICT skills.

3. Schools should be equipped with computer and Internet facilities and other necessary instructional tools like slide and video presentations.

4. Teachers should learn how to prepare lesson notes and instructional packages using ICT presentation methods.

\section{References}

[1] Amedeker, M. K. (2005). Reforming Ghanaian Teacher. Education towards preparing an Effective Pre-
Service Teacher. Journal of Education for Teaching, 31: 99-110.

[2] Ejedafiru, E. F. and Akporhonor, A. B. (2011). ICT and the Dynamics of University Education. Approaches in International Journal of Research Development. 4(1) 260271.

[3] Haddad, W. D. and Draxier, A. (2005). The Dynamics of Technologies for Education. [online] http://www.school netafrica.net/fileadmin/resources/emerging\%2010Trends\% 2020ICT\%2020challenges\%2010\%20eucational\%plannin. pdfschoolnet Africa [05 June 2009]. (Access Date: 25 May, 2016).

[4] http://www.interactiveeducation.ac.uk/. (Access Date: 11 May, 2016)

[5] http://www.4teachersorga.org/keynote/Roberts/ [15 April, 2009]. (Access Date 31 May, 2016).

[6] http://www.unescobkk.org/education/ict/themes/me asuring-and-monitoring-change/indicators-database-asiapacific-regional-survey/manual-for-pilot-testing-the-useof-indicators-to-assess-impact-of-ict-use-in-education/. (Access Date 31 May, 2016).

[7] Lafarriere, T., Breuleux, A. and Bracewell, R. (1999). Benefits of using Information Communication Technologies (ICT) for Teaching and Learning in K-12/13 Classrooms. Schoolnet, Canada.

[8] Lawal, H. S. (2003). Teacher Education and the Professional Growth of the 21st Century Nigeria Teacher. The African Symposium, Vol. 3.

[9] Maclkemenjima, D. (2005). E-Education in Nigeria: Challenges and prospects. Proceedings of the 8th UN ICT Task Force Meeting April 13-15, Dublin, Ireland. Obunadike, J. C. (2010). Implementation of ICT in Educational Curriculum to Enhance Learning in Primary and Secondary Schools in Anambra State. Approaches in International Journal of Research Development. 4(1), 169177.

[10] Olakulehin, F. K. (2007). Information Communication Technologies in Teachers Training and Professional Development in Nigeria. Turkey Journal of Distance Education TODJE, 8: 133-142.

[11] Ololube, N. P. (2005a). School Effectiveness and Quality Improvement: Quality Teaching in Nigerian Secondary Schools. African Symposium Journal of Africa Educational Research Network, 5:17-31.

[12] Ololube, N. P. (2005b). Benchmarking the Motivational Competencies of Academically Qualified Teachers and Professionally Qualified Teachers in Nigerian Secondary Schools. African Symposium Journal of Africa Educational Research Network, 5:17-37.

[13] Ololube, N. P. (2006). Teachers Instructional Materials Utilization Competencies in Secondary Schools in Sub-Saharan Africa: Professional and Non-Professional Teachers Perspective. Proceedings of the 6th International 
Educational Technology Conference EMU, April 19-21, North Cyprus.

[14] Osunde, A. U. and Omoruyi, F. E. O. (2004). An Evaluation of the National Teachers Institutes Manpower Training Programme for Teaching Personnel in MidWestern Nigeria. International Education Journal, 5:405409.

[15] Oyediran, W. O. and Omoare, A. M. (2014). Information and Communication Technologies (ICTs) Application in Agriculture: A Tool towards Rural Youths Empowerment in Ogun State, Nigeria. International Journal of Applied Research and Technology. 3(3): 33 38.

[16] Oyediran, W. O., Omoare, A. M., Eruaga, H., OkoOboh, E. and Omisore, O. A. (2014) Contributions of High Quality Cassava Processing Plant to Students' skill acquisition in cassava processing in Federal College of Education, Abeokuta, Ogun State, Nigeria. Annals of Youth and Child Studies, 5(1): 139 - 152.

[17] Roberts L. (2000). The Role of Technology in the Classroom (Online)

[18] UNESCO, (2003). Manual for Pilot Testing the Use of Indicators to Access Impact to ICT Use in Education.

[19] Yusuf, M. O. (2005). An Investigation into Teachers Self-Efficacy in Implementing Computer Education in Nigerian Secondary Schools. Meridian: A Middle School Computer Technology Journal, Vol. 8, Issue 2.

[20] Global Information Technology Report (2005). The Networked Readiness Index Rankings 2005. Retrieved 12th May, 2016 from http://www.weforum.org/pdf/Global _Competitiveness_Reports/Reports/gitr_2006/rankings.pdf (Access Date: 12 May, 2016)

[21] Chen, D. H., and Kee, H. L. (2005) A Model on Knowledge and Endogenous Growth World Bank Policy Research Working Paper.

[22] Federal Republic of Nigeria (FRN) (2004). National policy on education (4rd edition). Lagos: NERDC Press.

[23] UNESCO (2002). Information and Communication Technologies in Teacher education: A Planning Guide. Paris: UNESCO.

[24] Global Information Technology Report, (2004). The Networked Readiness Index Rankings. Retrieved $12^{\text {th }}$ May, 2016 from http://www.weforum.org/pdf/Global_Competitiveness_Reports/Reports/gitr_2006/rankings.pdf

[25] Obunadike, J. C. (2010). Implementation of ICT in Educational Curriculum to Enhance Learning in Primary and Secondary Schools in Anambra State. Approaches in International Journal of Research Development. 4(1), 169177

[26] Chiu, C. H. 2002. The effects of collaborative teamwork on secondary science. Journal of Computer Assisted Learning, 18, (3), pp. 262-271.
[27] Lipponen, L. 2000. Towards knowledge building: from facts to explanations in primary students' computer mediated discourse. Learning Environments Research, 3, (2), pp.179-199.

[28] Willinsky, J. 2000. Qualities of student-adult electronic communication: immediate, pedagogical, aberrant. International Journal of Educational Telecommunications, 6, (1), pp.3-18.

[29] Perry, D. 2003. Handheld computers (PDAs) in schools. Coventry:Becta.

[30] Becker, H., 2000. Pedagogical motivations for pupil computer use that lead to student engagement. Educational Technology, 40 (5), pp.5-17

[31] Harris, S. and Kingston, A., 2002. Innovative classroom practice using ICT in England: the second information technology in education study (SITES) http://www.nfer.ac.uk/research/down_pub.asp and Implications for schools http://www.nfer.ac.uk/research/ downloads/12.PDF (Accessed $29^{\text {th }}$ April 2016)

[32] Ofsted, 2001. ICT in Schools - The impact of Government Initiatives:an interim report. Ofsted.

[33] Lewin, C., Scrimshaw, P., Mercer, N., and Wegerif, R. 2000. The KS1 Literacy Evaluation Project Using Low Cost Computers. Open University Centre for Language and Communication

[34] Software and Information Industry Association, 2000. Research report on the effectiveness of technology in schools. Executive summary http://www.siia.net/Sharedcontent/store/e-edtech-sum00.pdf (Accessed 29 April, 2016)

[35] Boyd, O.M and Ellisor, N.B (2007) Social Network sites: Definitions, History and Scholarship. Journal of Computer-mediated Communication, 13 (1), article 11.

[36] Hedjazi, Y., Rezaee, R., and Zamani, N. (2006). Factor Affecting the Use of ICTs by Iranian Agricultural Extension Specialists. Journal of Extension System. 22(1): $1-5$.

[37] Jacobsen, D. M., and Kremer, R. (2000). Online Testing and Grading Using WebCT in Computer Science. Proceedings of WebNet 2000: World Conference on the World Conference on the WWW and the Internet, October 30 - November 4, San Antonio, Texas, USA 